doi: $10.12957 /$ childphilo.2019.39320

\title{
why piaget does not philosophize? critical discussion of gareth $b$. mathews with the piagetan concept of cognitive development
}

\author{
paweł walczak ${ }^{1}$ \\ university of zielona gora, poland \\ orcid id: https:/ / orcid.org/0000-0002-8541-0396
}

abstract abstract

This article analyzes the critique of the Piagetan theory of intellectual development made by American philosopher Gareth B. Matthews (1929-2011). Matthews analyzes Piaget's ideas from the perspective of the meaning and possibility of philosophizing among children. His use of Piaget is particularly relevant today because the theory of cognitive development has shaped modern education and contributes to the preservation of skepticism about children's philosophy. The article reconstructs and interprets Matthews' arguments, which consistently and systematically show that Piaget misunderstood children's philosophy. By "child's philosophizing," Matthews refers to children's tendency to ask philosophically significant questions, their ability to problematize experience, their specific attitude toward the world, and their ability to sense the problems that great philosophers have been dealing with for centuries. Piaget interpreted all these observable features of children's thinking as intellectual deficits; Matthews argues against this interpretation. The discussion focuses on the problem of determining the criterion of intellectual maturity, the importance of creativity and fantasy in thinking, the development of concepts and language skills, and the related differences between children and adults' language use. This analysis of Matthews' critique of the Piagetian theory of cognitive development concludes that child psychology needs to be more open to this aspect of children's thought and that psychologists and philosophers must seek to better understand the child's philosophizing.

key words: children's philosophy; cognitive development; piaget's theory; gareth $b$. matthews; philosophy of childhood

\section{¿por qué piaget no filosofa? discusión crítica de gareth b. matthews con el concepto de desarrollo cognitivo de piaget}

resumen

Este artículo está dedicado a la crítica de la teoría del desarrollo intelectual de Piaget, realizada por Gareth B. Matthews (1929-2011). Este filósofo estadounidense analiza los conceptos de Piaget (1896-1980) desde la perspectiva de la pregunta sobre el significado y la posibilidad de filosofar con niños y niñas. La discusión de Matthews con Piaget también puede ser interesante hoy en día debido al hecho de que la teoría del desarrollo intelectual en etapas ha dado forma a la educación moderna y es un factor que consolida el enfoque escéptico de la filosofía de niñas y niños. Este artículo reconstruye e interpreta los argumentos de Matthews, que demuestran de manera consistente y sistemática que Piaget no entendió el fenómeno de la filosofía infantil. Hablando del filosofar infantil, Matthews se refiere a la tendencia de los niños a formular preguntas filosóficamente significativas, a notar los problemas que los grandes filósofos han estado tratando durante siglos, la actitud

1 E-mail: p.walczak@ifil.uz.zgora.pl 
why piaget does not philosophize? critical discussion of gareth $\mathrm{b}$. mathews with the piagetan concept of cognitive development

específica de niñas y niños hacia el mundo y su capacidad de problematizar la experiencia. Todas estas características observables del pensamiento de niñas y niños fueron interpretadas por Piaget como déficits intelectuales. Matthews argumenta en contra de tal interpretación. La discusión se refiere a cuestiones tales como: el problema de determinar el criterio de la madurez intelectual, la importancia de la creatividad y la fantasía en el pensamiento, el desarrollo de conceptos y habilidades lingüísticas y las diferencias entre el uso del lenguaje por parte de niños y adultos. El análisis de la crítica de la teoría del desarrollo intelectual de Piaget lleva a la conclusión de que la psicología infantil necesita cierta apertura a este aspecto del pensamiento de niñas y niños, ignorado por Piaget. Todavía hay una tarea importante para que psicólogos y filósofos comprendan mejor el fenómeno del filosofar infantil.

palabras clave: filosofía infantil; desarrollo intelectual; teoría de piaget; gareth b. matthews; filosofía de la infancia.

\section{por que piaget não filosofa? discussão crítica de gareth $b$. matthews com o conceito de desenvolvimento cognitivo de piaget}

resumo

Este artigo é direcionado a criticar a teoria piagetiana do desenvolvimento intelectual elaborada por Gareth B. Matthews (1929-2011). Este filósofo americano analisa as ideias de Piaget (1896-1980) de uma perspectiva da questão sobre o significado e a possibilidade de filosofar com crianças. A discussão entre Matthews e Piaget pode parecer interessante hoje porque a teoria do desenvolvimento cognitivo tem moldado a educação moderna e pode ser vista como um fator de perpetuação de posturas céticas diante da filosofia para crianças. Neste artigo, os argumentos de Matthews foram reconstituídos e interpretados, provando consistente e sistematicamente que Piaget não compreendeu o fenômeno da filosofia das crianças. Falando do filosofar das crianças, Matthews está se referindo à tendência das crianças de perguntar questões filosoficamente significativas, à habilidade de problematizar a experiência, à atitude específica das crianças para com o mundo e a notar os problemas que grandes filósofos têm lidado por séculos. Todas essas capacidades observáveis do pensamento das crianças foram interpretadas por Piaget como déficit intelectual. Matthews argumenta contra esta interpretação. A discussão enquadra estas questões como sendo um problema de determinação do critério de maturidade intelectual, de importância da criatividade e da fantasia no pensamento, de desenvolvimento de conceitos e de habilidades linguísticas e de diferenças entre o uso da linguagem entre crianças e adultos. A análise das críticas da teoria piagetiana do desenvolvimento cognitivo leva à conclusão que a psicologia infantil precisa de abertura a este aspecto do pensamento das crianças que Piaget ignora. Há ainda uma importante tarefa para psicólogos/as e filósofos/as em melhor entender o fenômeno do filosofar por parte de crianças.

palavras-chave: filosofia para crianças; desenvolvimento cognitivo; teoria de piaget; gareth $b$. matthews; filosofia da infância. 
why piaget does not philosophize? critical discussion of gareth $\mathrm{b}$. mathews with the piagetan concept of cognitive development

\section{introduction}

For a number of years, the phenomenon of child philosophising has been a focus of philosophers and education specialists, but it has been particularly gripping to all those, who deal with children on a daily basis: parents and teachers. Ever since Aristotle the philosophers have viewed child philosophising as an expression of a natural need of human reason, which strives to find out the truth. However, since child's cognition has its limits, its philosophising is imperfect and, as a result, in opinions of many philosophers is considered not worthy of attention. There are, however, philosophers, who consider such inquiries made by children as a source of all philosophy and refer to children as natural philosophers, hence the "adult" philosophy is viewed as a more or less successful attempt at coming back to this original attitude, naturally taken by children. Gareth Matthews, one of the tireless promoters of the notion of child philosophising, is convinced that their tendency to engage in philosophical considerations tells us a lot about children themselves and man in general. He also notices that this natural tendency is ignored by various educational systems, which can be the source of many contemporary pedagogical failures. Te absence of child philosophy in educational theory and practice can be related to an insufficient level of analysis of this problem within the developmental psychology and especially to a negative approach to the philosophical character of child thinking by the leading figure in the field of child cognitive development - Jean Piaget.

What Matthews has in mind when talking about child philosophy? What he means is the tendency of children to pose philosophically-significant questions, their ability to problematize the world and to notice problems that for centuries have been the object of analysis by some of the greatest philosophers. Matthews also observes 
why piaget does not philosophize? critical discussion of gareth $\mathrm{b}$. mathews with the piagetan concept of cognitive development

that children, when answering such questions build theories that are similar to the solutions proposed by many thinkers in the past (MATTHEWS, 1994, p.33).

This article is an analysis of Gareth Matthews's arguments against Piaget's theory of the development of cognitive competences in children. Matthews's interest in Piaget's theory arises in the context of the phenomenon of child philosophy. ${ }^{2}$ The starting point of this analysis is the question of what causes relatively low levels of interest by psychologists and education specialists in child philosophy. We focus on the role played in such low levels of interest by the fact that Piaget himself was not very interested in a philosophical dimension of child thinking. By critical analysis of Matthews's arguments that are aimed against methodological and factual bases of Piaget's theory, we attempt to answer the question why Piaget doubts in the phenomenon of child philosophising. In our opinion, expressed in the conclusions to this article, Gareth Matthews tackled an important problem, hence a reconstruction of his polemic with Piaget can be an inspiration to education specialists, teachers and parents alike to undertake the effort to better understand children and enter with them into a creative discussion.

The global child philosophy movement, connected to such figures as Matthew Lipman (1923-2010) and Gareth Matthews, proposes an approach to child thinking that is opposed to education based on Piaget's developmental theories. Richard F. Kitchener in his Do Children Think Philosophically? emphasises that "children's philosophy movements present a serious challenge to Piaget's views about epistemology, psychology and education" (KITCHENER, 1990: 422). We believe that Matthews managed to tease out the main, previously overlooked, problems in Piaget's approach. The analysis of Mattews's arguments against Piaget allows one to describe the impact of the phenomenon of child philosophising and perhaps to justify

\footnotetext{
2 I study Matthews' discussion with Piaget's conceptions on the basis of the arguments contained in the following Matthews works: Piaget (in: MATTHEWS, 1980); Developmental psychology (in: MATTHEWS, 1984); The idea of conceptual development in Piaget (1985); Piaget and philosophy (in: MATTHEWS, 1994); Piaget and conservation (in: MATTHEWS, 1994);
} 
the need for a more thorough analysis of this phenomenon and placing it the framework of educational theories.

\section{why psychologists are not interested in child philosophizing?}

Contemporary educational systems are based on theories relating to specific notions of human cognitive development. Given this, one can be excused for thinking that the phenomenon of child philosophizing is not treated seriously or taken into account in the analyses conducted by developmental psychologists. According to Matthews, one of the causes of this situation is related to the fact that child's spontaneous comments of philosophical character are rather non-frequent and nonstandard occurrences, whereas psychologists tend to focus on a more standard behaviour. How one should approach the ability of children to philosophise, which clearly shows up in so many conversations Matthews have had with children and described in his books? Why there is no space for such abilities in the developmentalist's profile of the preadolescent mind? (MATTHEWS, 1984: 116)

Such a state of affair has no doubt a number of causes. It should be emphasised that psychological theories focus on the competences that are considered important from the point of view of society. As the ability of philosophical thinking and discussing the basic questions is often considered impractical and viewed as one that does not bring measurable benefits, one should not be surprised by the fact that such skills are not deemed worthy of attention by the researchers and hence the development of philosophical thinking in children is not investigated. Moreover, the developmental psychology has accepted a biological model of development, where it is an adult individual that is considered a standard. By referring to this standard, the researchers can describe developmental stages of the process of maturing. In the case of philosophical thinking, however, one might have problems in pointing to such a standard. Whereas, for example in terms of mathematical skills, the experts would be able to define the notion of maturity, it would be much harder a task in the case of philosophy (MATTHEWS, 1984: 117). However, according to Matthews, the theory of 
why piaget does not philosophize? critical discussion of gareth $\mathrm{b}$. mathews with the piagetan concept of cognitive development

cognitive development of Jean Piaget, who, as a pioneer in the research on child cognitive development, has become a point of reference to many researchers focusing on child mentality, is by far the most important factor behind the indifference of psychologists and education specialists towards child philosophy. His theories have had an enormous impact on the way, in which the thoughts of children are interpreted and analysed and, in consequence, on the shape of the educational systems themselves. The experiments designed and conducted by Piaget have also played a crucial role: the results of such experiments are surprising and astonishing for us as the reactions of children turn out to be quite different to what we expect (MATTHEWS, 1994: 30-31). In addition, such experiments are repeatable, hence potentially can be conducted at any given moment and place. Their essence lies in a specific way of asking questions and a methodical interpretation of the answers provided. Such experiments show certain patterns related to the age of children, described by Piaget using the theory of stages of cognitive development. As a result, analysing the same child over specified time intervals, we can expect its reactions to change in a predictable manner. According to Matthews, it is those features of Piaget's experiments that convince us of the validity of his theories; as a result, these theories have proved to be extremely popular and influential in shaping the evolution of developmental psychology. Matthews writes:

Only a first-rate genius could think of lots of experiments that all, or almost all, have these three features. These three features, by themselves, go a very long way toward selling us on Piaget's theory. Perhaps better: these very general features of Piaget's experiments are pretty much enough to sell most people on the general idea of a Piagetian theory of cognitive development, with really very little regard for what the detailed content of that theory turns out to be. (MATTHEWS, 1996: 31).

Matthews's skepticism towards Piaget's theory is clearly visible. He claims that the very fact that the experimental results are surprising to us indicates that we do not really know our children. Piaget's experiments make us aware that in many respects children are markedly different to adults, almost as if they had been the representatives of other, alien, world or culture. This, in turn, evokes the need to seek expert advice and to establish theories that explain the way the children are and how 
they think. We should remember, however, that Matthews is interested in Piaget in relation to the question of philosophizing with children and it is in this context that he often harshly critiqued Piaget's theory in his articles, showing its weaknesses and inconsistencies.

\section{do children philosophize?}

The basic objection by Matthews against Piaget's theory is that when Piaget analyses the child way of interpreting the world, he does not take the philosophical character of child's answers into account. As a result, he uses theoretical tools, which are not fully suitable for the analysed problem, hence the attempts at measuring the development of the way of interpreting the world, which is philosophical in its essence, using psychological and biological categories which are doomed to produce ill-founded conclusions and to result in ignoring significant aspects of child thinking. The logic of this argument is exemplified by Matthews's comment on Piaget's The child's conception of the world (1929), where Piaget discusses and analyses the answers given by children to the questions that are philosophical in their essence: What is thinking? What is the relation between a word and a meaning? What are dreams and where are they located? What counts as a living thing and what counts as a conscious being? One would expect, after a set of such questions had been presented, an attempt at reconstructing the philosophical structure of child's answers, however, this aspect is ignored by Piaget as a result of the reductionist character of his scientific approach. What is the essence of this reductionism?

The basic research procedure utilised by Piaget assumes the development of child's thinking and child's way of answering the above questions according to the law of stages of development. Such an approach raises justifiable doubts in relation to philosophical reflection, and since Piaget's questions are definitely of philosophical character, the answers do require philosophical reflection and the problem arises whether one can really talk about a certain "standard" or "norm" in terms of development. Is it possible to set such a standard in the case of philosophical 
why piaget does not philosophize? critical discussion of gareth $\mathrm{b}$. mathews with the piagetan concept of cognitive development

reflection? Can one, and if so, then to what degree, talk about more or less "mature" answers to philosophical problems? In what way such a maturity would be measured? The problem lies in the fact that Piaget, by not taking into account the philosophical character of the analysed visions of the world hidden in children's answers, prevents himself from even asking this sort of questions. What is important from the point of view of Piaget's procedure is to determine the stages of development on the basis of the recurring elements in the children's answers. Nonstandard answers are treated by him as an "uncertain indicator" of child thinking, hence are rejected as irrelevant for determining the general tendency. Yet, it is precisely those non-standard answers that are the most important from the point of view of philosophy. Most likely that, which is philosophically most interesting and which is not expressed in the form of thought-over theories, was dismissed by Piaget as "romancing" (PIAGET, 1929: 10).

This, reductionist, approach, consisting of ignoring the philosophical dimension of child thinking, leads to the acceptance of not-sufficiently-justified category of "maturity" by Piaget; category, which is the basis for evaluating and placing children along the scale of cognitive competences.

A question suggests itself at this point whether, and if so, then in what sense, the theories formed by the children on the world that surrounds them, as analysed by Piaget, are of philosophical character. Does the decisive factor lie in the very questions children answer or rather in the way, in which they choose to answer such questions? Matthews argues that the philosophical character of child inquiries is supported mainly by the fact that the ideas expressed by children correspond with various theories formulated by philosophers over the ages. Simply put: children say the same thing as the philosophers but using different language. This approach of Matthews is well exemplified by his comment on Piaget's analysis of the answers given by children to the question: "what is thinking". ${ }^{3}$ Matthews sees certain

\footnotetext{
${ }^{3}$ Piaget claims that there are three stages of gradual development of child's understanding of what thinking is. In the first stage, (at the average age of 6), children believe that thinking happens with the mouth; thought is identified with voice and located neither in head nor in any other bodily part. In the
} 
similarities between the answers given by children as reported by Piaget and certain philosophical theories. The classical theory of thinking, formulated by Plato (thought as an inner voice) is connected by Matthews to the answers given by children, classified by Piaget as belonging to the first stage. (MATTHEWS, 1980: 42-43) Some later theories referred to and developed Plato's ideas, for example P.T. Geach's ${ }^{4}$ theory of propositions or the theory of John B. Watson, one of the founding fathers of behaviourism, which is even more closely related to Piaget's first stage. According to Watson, thinking is the effect of conditioning related to situations when adults try to curb the cries of newborns. Reacting to adult's admonishings, a child gradually moves towards soundless speech, which eventually becomes thinking. Matthews believes that Piaget's second stage is related to a number of materialistic theories of thinking, including identity theories, where all mental events are considered identical with the processes occurring in the brain. The second stage in Piaget's classification is related to a classical dualism, especially to the notion of images, as described by empiricists (MATTHEWS, 1980: 43-44).

For Piaget, what was characteristic of the first stage is the belief of children that "there is nothing subjective in the act of thinking", which is considered by him as a sort of disadvantage. This disadvantage is gradually overcome in the subsequent stages. As a consequence of this approach, the philosophers such as Geach, who develop the notion of thinking as an internal speech, should be considered handicapped or, in one way or another, mentally challenged. Those in support of the theory of identity are better developed in relation to those supporting the first-stage theories - however, according to the theory of stages of development, these too should, in some sense, be considered intellectually deficient. In terms of philosophy, it is hard to compare behaviourism and materialism or dualism claiming that the

second stage (at 8 years of age), the influence of adults on children and the way, in which they understand what thinking is becomes visible: children learnt from adults that we think with the head or brain (located in the head). Yet, it is still, according to children at this stage, a kind of a voice located in the head or neck. It is only during the development of the process that thought is gradually materialised by children as having something to do with air, blood etc. In the third stage (at 11-12 years of age), the thought appears to be non-materialised (PIAGET, 1929: 37-60).

${ }^{4}$ Peter Thomas Geach - a British philosopher of Polish descent, the author of Mental acts (1971).

childhood E philosophy, rio de janeiro, v. 15, jan. 2018, pp. 01- $25 \quad$ issn 1984-5987 
why piaget does not philosophize? critical discussion of gareth $\mathrm{b}$. mathews with the piagetan concept of cognitive development

former is more or less "deficient", with the latter being in some sense its corrected version.

Obviously, Piaget himself does not directly state that the six-year-olds support behaviourism, the eight-year-olds develop identity theory, whereas the twelve-yearolds are dualists. He merely says that, if one asks a six-year-old "with what do you think?", one can expect the answer "with mouth", two years later one can hear "with head" or "with brain". Matthews emphasises however, that Piaget was more interested in the child's conception of the world - in this case the conception of thinking, and one cannot claim that he merely summed up the answers given. He himself assumed that his task lies in discovering the child's theories of thinking, separating it from the ways, in which this conception is being expressed by children as the words used by them are "necessarily inadequate" (PIAGET, 1929: 27). Hence we can also use the classical theories of thinking, which relate to the theories developed by children but are expressed differently. An important question remains to be asked, namely does Piaget assume that a behaviourist is someone, whose conception of thinking never surpasses the first stage? Or does he perhaps assume that behaviourists go through all three stages but then come back to a theory that can be classified as belonging to the First stage? (MATTHEWS, 1980: 46)

We see then that in the context of child philosophy, the theory of sequential development generates the problem of cognitive maturity of a child and hence its readiness to philosophise. If philosophising requires mental maturity, children, being in the early developmental stages, given their cognitive capabilities, cannot philosophise and there is no point in encouraging them to do so. If this is the case, it would also be absurd to think that philosophising is a natural activity of children. On the other hand, if we accept that children do philosophise, it may mean that philosophising as such is an activity of an immature mind. In such a case, it is also pointless to encourage children to do it, as philosophising is then their natural activity, which will wane in the process of their cognitive development. Unfortunately, one of the consequences of this solution is that one has to accept that 
adult philosophising is also an expression of their mental immaturity. Given such inconsistencies of Piaget's theory, Matthews tries to point to other possibilities.

According to Piaget, the notion of child philosophy can be but a simplification. He himself defines child philosophy as the way, in which children imagine the world, natural events, mind, speech, life and consciousness to work. The ways, in which children imagine and form theories, utter "unconnected and incoherent spontaneous remarks" (PIAGET, 1933: 534) are then collected and classified by Piaget, who describes them as animism, realism, artificialism, etc. On the basis of this classification Piaget builds his theory of sequential development. He, however, clearly states that the phrase 'child philosophy' should not be treated in a way similar to other phrases of this kind as it is not, strictly speaking, a proper philosophy, since children are not capable of developing it. Supporting this point of view, Richard Kitchener argues that child philosophy is a concrete, as opposed to abstract, philosophy. Kitchener writes: "These dialogues include discussions of death, dreaming, do plants have feeling?, bravery, the material composition of cheese, the ship of Theseus, time travel, sharing the TV, do computers think?, are people animals?, etc. Many (but not all) of these issues have the property that they are about concrete examples instead of general principles. Young children may do philosophy concerning concrete philosophical issues, but whether young children can do philosophy concerning abstract philosophical issues remains presently unclear" (KITCHENER, 1990: 427). In addition, children lack certain cognitive competences that are crucial in developing true philosophy, related to higher-level reflection and abstract thinking about the rules, which are described by Kitchener as higher-order logical skills. He emphasises that these, despite being conditions for developing true philosophy, are not identical with philosophising (KITCHENER, 1990: 421-422).

Matthews's views on child philosophy have their source in his rich experience in terms of long philosophical discussions with children (MATTHEWS, 1980; 1984). He calls up many examples of the opinions of children that, according to him, correspond very well with the classical theories put forward by great philosophers; in 
why piaget does not philosophize? critical discussion of gareth $b$. mathews with the piagetan concept of cognitive development

simple terms, these are the same philosophical problems and ideas that were formulated by great philosophers but expressed in a different way that was appropriate for children. Let us recall one particular example:

„When Ian (...), age six, protests to his mother that the three unpleasant children of his parents' visiting friends have taken over TV set and kept him from watching his favorite program, he asks provocatively, <<why i sit better for three people to be selfish than for one?>> Deftly he turns on its head the utilitarian justification for particular case of aggrandizement, namely $<<$ Three people are being made happy, rather just one >>" (MATTHEWS, 1994: 33).

Matthews considers Ian's question to be a true philosophical problem formulated in a spontaneous and natural way. Even if we agree that the question has been raised as a result of frustration or anger - we also have to concede that similar problems are being tackled by philosophers during various debates and conferences and it may happen that they are also - as Matthews puts it - "motivated by rage or frustration, or by the need to get a job, rather than the pure love of wisdom" (MATTHEWS, 1994: 34).

The problem whether philosophizing counts as a mature activity is sidestepped by Piaget, when he comes up with an explanation akin to the recapitulation theory. He does this, for example, in his Children's Philosophies (1933), where he posits that child's cognitive development recapitulates the history of Western philosophy, going through stages related to particular phases of European thought, from the pre-Socratics to Kantists (MATTHEWS, 1994: 34-35). The problem with this approach is that one has to accept that the history of Western philosophy can be viewed as a process of development, of maturation. Yet, it is hard to argue against the thesis that Plato was at least as mature as contemporary philosophers.

The development of philosophy is related to the growth of knowledge, the deepening of our understanding of facts. Also, a lot more information is at the disposal of the thinkers living in later eras, compared to those living before them. Evaluating the cognitive maturity of an ancient philosopher by referring to his 
knowledge of the world as viewed from our contemporary perspective leads to nonsensical conclusions. As a result, Matthews seems to have argued that what is described by Piaget in categories of the development of cognitive competences can be influenced to the greatest degree by the growth of knowledge and experience. This is obviously related to the person's age, as one gains knowledge and experience with age, but, perhaps, it is experience, rather than age, that is a decisive factor here. $R$. Kitchener, who is defending Piaget in that respect, demands an empirical proof: "this claim has little empirical backing to support it, however; certainly no one in the philosophy for children program has provided such evidence that developmental differences can be washed out via enriched learning experience". (Kitchener 1990, p. 229) However, Piaget himself also did not present a sufficient proof that it is age and not the growth of knowledge or experience that is the decisive factor in terms of developmental differences.

\section{evolution of ideas or extending knowledge?}

The problem of the impact of experience on the development of a child is also tackled in the article The idea of conceptual development in Piaget, where Matthews analyses Piaget's theory of evolution of ideas (MATTHEWS, 1986).

Piaget is considered the creator of the idea of the development theory, referred to by Matthews as Evolutionary Model with Non-Identity Thesis ${ }^{5}$. This theory assumes that the ideas evolve slowly from their predecessors, forming a series of "proto-ideas" that are different to the ideas used by adults. Such an evolution of ideas is correlated to the stages of the development of cognitive competences. The non-identity thesis relating to the child and adult ideas suggests that the world of child ideas is not

5 The evolutionary Model:

- The child acquires the concept in question, $C^{*}$, by first acquiring a predecessor concept, $C 1$, and perhaps by then acquiring one or more intermediate concepts, $\mathrm{C} 2, \mathrm{C} 3, \bullet \cdot \bullet$, as well.

- Each concept of the series, CI... $C^{*}$, displaces its predecessor, if any, in that whereas the child had used word (or phrase) $w$ to express $C 1$, the child later uses $w$ to express $C 2$, etc.

- Each concept in the series, $\mathrm{Ca} . . ., C^{*}$, except, of course, the first concept, C1, evolves out of the concept it displaces.

the non-identity thesis: No child's concept that is displaced by a later concept (either simply, or by evolution) is identical with any adult concepts (MATTHEWS, 1986: 91).

childhood E philosophy, rio de janeiro, v. 15, jan. 2018, pp. 01- $25 \quad$ issn 1984-5987 
why piaget does not philosophize? critical discussion of gareth $b$. mathews with the piagetan concept of cognitive development

merely a poorer and simplified version of the world of adult ideas but rather akin to an interesting world of ideas of some primitive alien culture, which is hard to be fully understood by those analysing it. If this is augmented with an assumption that our ideas evolved from this primitive world of ideas, one sees that analysing this world is important for us as it can enrich the understanding of our world of ideas - as the analysis of primitive societies from which our society originated can help us understand the contemporary social mechanisms. Interestingly - one does not really encounter such reflections related to and motivations for analysing the world of child ideas in Piaget's works, as this would be tantamount to accepting and taking into account the notion of philosophical reflection in the dialogue with children. Matthews is predominantly interested in whether Piaget provides sound evidence that his model of development of ideas is adequately describing the way children acquire ideas, which heavily bears on the problem in the context of the value of child philosophizing.

Matthews focuses on the example of child ideas of "life" and "consciousness" as described by Piaget and he tries to analyse the evolution of such ideas in children. In his The child's conception of the world Piaget writes:

"During the first stage everything is regarded as living which has activity or a function or a use of any sort. During the second stage, life is defined by movement, all movement being regarded as in a certain degree spontaneous. During the third stage, the child distinguishes spontaneous movement from movement imposed by an outside agent and life is identified with the former. Finally, in the fourth stage, life is restricted either to animals or to animals and plants" (PIAGET, 1929: 194-195).

As one would be hard pressed to find the explanation of the mechanism of going from one stage to the other, Matthews posits that a child, by undertaking a gradual effort to understand adult words, tests its understanding by means of a series of analytical hypotheses. Taking the idea of "life", the hypotheses at various stages could look as follows:

First Stage: $x$ is alive $=\mathrm{df}: \mathrm{x}$ is active or $\mathrm{x}$ has a use or $\mathrm{x}$ has a function of some sort. 
Second Stage: $x$ is alive $=\mathrm{df}: \mathrm{x}$ can move.

Third Stage: $x$ is alive $=\mathrm{df}: \mathrm{x}$ can move spontaneously (MATTHEWS, 1986: 94).

What about the Fourth Stage? According to Matthews, Piaget's description that "life is restricted either to animals or to animals and plants", can assume the following extensional hypothesis:

The expression, 'is alive', can be correctly applied to any plant or animal, and only to such, which turns out to be false as many plants and animals are dead. However, could Piaget reasonably assume that when a child of around 11-12 years of age says that something is alive then it thinks that it is a plant or an animal? Surely not. Piaget should rather assume that the child, by acquiring the adult idea of life, adds a certain specification (characteristics) to the Third Stage when stating that a given object is a plant or an animal, hence:

Fourth Stage: $x$ is alive $=\mathrm{df}: \mathrm{x}$ is a plant or $\mathrm{x}$ is an animal; and $\mathrm{x}$ can move spontaneously.

As a result, Matthews questions the adequacy of the description of the process of going from one developmental stage to the next in the model of evolution of ideas as proposed by Piaget. The non-identity thesis seems untenable, as adults most certainly utilise the ideas assumed here: action, use, function, movement and spontaneous movement. It can be argued that describing the intellectual development as a succession of analytical hypotheses understandable by adults is incompatible with the non-identity thesis, as such analytical hypotheses are understandable to them, hence make use of the ideas that are adults are also familiar with. In the end, Matthews posits the formulation of a different framework, described by him as a Specification Model - where it is assumed that child goes from the First Stage to the Fourth Stage by learning the proper use of the following expressions:

(a) can do something.

(b) can go (that is, can move).

(c) can go by itself (herself, himself).

(d) is alive. 
why piaget does not philosophize? critical discussion of gareth $\mathrm{b}$. mathews with the piagetan concept of cognitive development

Hence, in the First Stage, a child can use all these expressions interchangeably and the meaning of "alive" is being limited in subsequent stages: firstly to what moves, then to what moves independently, and finally it distinguishes independently moving plants and animals from others, which do not have this feature.

In the fragments referred to by Matthews, Piaget seems to have assumed that he, his readers and the children that he talked to already possesed the relevant notions. What Piaget calls the evolution of the idea of life turns out to be nothing more than a gradual and more precise description of an empirical generalisation or a process of making the extensional hypotheses more precise, hence more relevant. Of the development of concepts I can find no clear conception - says Matthews (MATTHEWS, 1986: 97). This conclusion has an enormous bearing on the question whether children are mature enough to philosophize. Piaget's model of development implies the necessity of concluding that children lack competences to address philosophical questions and to undertake a valuable philosophical reflection. The evolutionary model of development also assumes that children use different notions, excluding the possibility of a meaningful philosophical dialogue between children and adults. Matthews, by pointing to the weaknesses of this model tries to justify the thesis that what differentiates children and adults in terms of philosophical consideration is not the lack of cognitive competences but merely the amount of knowledge and experience. The child-specific way of formulating questions and thoughts of philosophical character does not mean that children lack the ability of logical thinking, but rather that it is an effect of insufficient linguistic practice related to the fact that children just started learning how to communicate in a given language. Children need to experiment and test the meanings of concepts used by adults but the factors that are the most important in philosophical consideration, namely is curiosity, creativity, reflection, rich imagination and thinking outside the box, do not emerge in children gradually according to the stages described by Piaget but are natural elements of child's mentality and, what is important - appear independently of age. The problem is the impact that Piaget's theory had on the way children and 
their development are approached. The approach to children based on Piaget's ideas would treat child's thoughts as valueless, assuming their cognitive immaturity. Since children do not philosophize as they lack the ability to do so, one would do wise to ask what sorts of cognitive deficiencies made it impossible for them to engage in valuable philosophical investigations?

\section{what do children need in order to philosophize?}

Piaget's theory explains the cognitive development of a child by describing it as a gradual overcoming of certain mental, intellectual and linguistic barriers, which can be described as cognitive deficits. Such conclusions are based on the research described by Piaget and Barbel Inhelder in The child's Construction of Quantities: Conservation and Atomism (PIAGET, INHELDER 1974), which focuses on the understanding by children of notions such as conservation of substance, weight and volume. The experimental design was as follows. The child had observed as certain substances were being deformed (flattening of a clay ball, dissolving a sugar cube in water, making of popcorn) and then was asked about the amount, weight and volume of a given substance before and after the deformation. Piaget and Inhelder, summing up their experiments, state that the answers given by children can be classified according to the four stages:

Stage I up to age 7 or 8

Stage II (A, then B) 8 to 10

Stage III (A, then B) 10 to 11 or 12

Stage IV (A, then B) 12 end on

The answers given by children at various stages show the increase of the awareness of conservation of substance, weight and volume. The Stage I children said that the amount of clay is reduced when the ball is being flattened, after the deformation it weights less and has a smaller volume. In the Stage II, the idea of conservation of substance emerges - children said that the amount of clay does not change but misjudged the amounts of weight and volume. In the Stage III, children 
why piaget does not philosophize? critical discussion of gareth $\mathrm{b}$. mathews with the piagetan concept of cognitive development

started to notice the conservation of weight, in the Stage IV they developed the idea of conservation of volume, as a logical necessity deduced from the principle of conservation of weight. A similar pattern was observed by the authors in relation to the experiments with dissolved sugar and popcorn.

Piaget and Inhelder claim that children "construct" or "discover" these principles (of the conservation of substance, weight and volume). However, a question remains with regard to a precise formulation of the principles constructed, or discovered, by children. Matthews emphasises that the authors neither formulate nor describe in more details these principles in their text, hence he proposed the following formulation (CS - conservation of substance, CW - conservation of weight, $\mathrm{CV}$ - conservation of volume):

"(CS) One will end up with just us much stuff as one started out with, so long as no stuff has been added or taken away.

(CW) One will end up with something that weight exactly as much as it did at beginning, so long as no stuff has been added or taken away.

(CV) One will end up with something that displaces exactly as much liquid as it did at the beginning (...), so long as no stuff has been added or taken away" (MATTHEWS, 1994: 44-45).

The formulation of these principles allows one to undertake a detailed analysis of what really happens when children gradually come to accept them. According to Matthews, during the Stage I, children have the tendency to prioritise certain dimensions over others. Hence, seeing that a given thing became longer, children would think that it also became bigger. The Stage II is related to a gradual acceptance of the mixture of the principle stating that nothing comes out of nothing and the principle stating that nothing passes away into nothing, which together with the acceptance of the principle that substance cannot be transformed into anything that is not substance create, what Piaget calls, the conservation of substances (CS). It is in the Stage III, when children develop the notion of weight, that they begin to understand that deformation and dissolving are related to re-organisation of particles consisting a given object. Weight of the whole is then viewed as a sum of the weights of the parts constituting a given object. Hence, neither deformation, nor dissolving can change the 
weight. During the Stage IV, children begin to notice the three-dimensionality of objects, which allows them to develop the notion of a volume. They notice that some deformations result in changing the total volume of an object with leaving volume unchanged at the same time. Matthews is fascinated by the fact that at this stage, children by themselves come up with an idea that the differences between the weight of the objects with the same volume can be explained by a tighter or looser "packing" of particles in the object. Matthews points out that this is a rephrased version of a classical atomism. „How is one to evaluate this great story or intellectual adventure seems to repeat itself in the life of each normally developing child?" - Matthews asks (MATTHEWS, 1994: 47).

It is the answer to this question that reveals the fundamental difference between him and Piaget. The fact that children do discover such principles is for Matthews a sign of their truly philosophical needs that are realised in what he calls a "natural exercise in speculative metaphysics" (MATTHEWS, 1994: 47). Whereas for Piaget, it is an evidence for a gradual overcoming of certain intellectual limitations, which is tantamount to acquiring certain cognitive competences allowing one to start viewing the world in the adult way. Piaget and Inhelder describe such deficits as egocentrism and phenomenalism, the meaning of which Matthews tries to reconstruct:

Piaget's idea seems to be that children at the earlier stages are phenomenalists because they are wedded to the appearances (phenomena), that is, to how things seem. They are egocentric in that each child translates all questions about quantity into questions about how much there seems to be to me. (MATTHEWS, 1994: 48).

There is no doubt that Matthews does simplify matters here but there are good reasons to ask whether on the basis of Piaget's experiments one can correctly deduce that children are characterised by egocentrism and phenomenalism. If a child age 8 (Stage II) affirmatively answers the question whether a rolled piece of clay is heavier than the same piece when it was flat, then Piaget concludes that the child interprets the question to mean whether for him or her this rolled piece of clay is heavier than the same piece when it was flat. Matthews does not understand why this would be an 
why piaget does not philosophize? critical discussion of gareth $b$. mathews with the piagetan concept of cognitive development

evidence of child's egocentrism or phenomenalism: as it is as early as the Stage II that - according to Piaget's own theory - this child gradually discovers the nonphenomenal principle of the conservation of substance. Moreover, in this very stage, the child, when asked what happened to the dissolved sugar answers that it is still in the water as small particles, which are too small to be seen, even when using a microscope. "This hardly justifies a claim of childhood phenomenalism" - Matthews writes (MATTHEWS, 1994: 48).

Egocentrism in the described stages of development can be seen either as a lack of interest or an impossibility to imagine the way, in which objects are perceived by others, or the way, in which these present themselves from various points of view. According to Matthews, Piaget and Inhelder do not analyse whether children are interested in other points of view. They try to argue that children are incapable of imagining a given object from a different point of view. Matthews quotes the authors describing egocentric approach of a child to the problem of weight. According to them, the child considers weight a non-measurable quality that influences the scales in the same way, in which the human hand does. Matthews, puzzled by such an explanation, writes: "Their idea seems to be that these children are egocentric because they are poor at imagining how the clay will feel to the balance! Surely that is a very bad way of understanding what is going on" (MATTHEWS, 1994: 50). According to him, a better explanation is that a child learns to distinguish between how things are perceived by us and how they are in reality. Experimenting with scales would only help the child in pinning down this difference. That is why Matthews concludes that "the claim that these conservation findings show children gradually overcoming egocentrism and phenomenalism is unsubstantiated" (MATTHEWS, 1994: 50).

Nevertheless, the discovery of the mentioned principles is something for which the authors should be rightly commended, but which is no so much related to overcoming cognitive deficits as it to something that can be described as a great intellectual adventure of childhood, a "wonderful exercise in rationalistic metaphysics" (51). Children, akin to great philosophers, try to go beyond the sensual 
experiences and discover the principles governing all phenomena. That is why Matthews takes issue with treating child's philosophical thinking as merely an intellectual play that has no greater bearing on the cognitive development. The stages described by Piaget and Inhelder are not related to a gradual acceptance of truths but rather to a formulation of intellectually satisfying principles. Therefore, it is not the development understood as "step-by-step victory of truth over falsehood" but rather: a "wonderful intellectual construction. It is, in fact, a philosophical construction." (52) Matthews points out that Piaget assumes the validity of $C S, C W$ and $C V$, and on the basis of this assumption defines the developmental stages. Since children initially do not observe such principles and then gradually come to accept them, and since these principles are valid, one can describe such process as a development; a child moves from ignorance to knowledge. Piaget, focused on forming the developmental model, does not notice and does not understand the phenomenon of child philosophizing. Children do make mistakes (i.e. are not right) at every stage of development. However, their mental constructs are in reality a brilliant philosophical problematisation of the world. Matthews believes that Piaget is not interested in philosophical considerations in general, hence his lack of interest in child philosophizing in particular.

\section{why Piaget does not philosophize?}

According to Matthews, some people are resistant to philosophical puzzlement: for them the world is full of objects that one can have some knowledge of but there is nothing there that would truly astonish such individuals. He goes on to suggest that Piaget seems to be that kind of a person and that is the reason, why he is unable to enter into a philosophical discourse with children: "That philosophy can Begin with a child in so simple a way says something important about philosophy, an something important about children. It is something that Piaget has missed" (MATTHEWS, 1980: 55). Piaget's remarks suggest that it would have been something insane, whimsical and irrational to expect that children say something 
why piaget does not philosophize? critical discussion of gareth $b$. mathews with the piagetan concept of cognitive development

philosophically interesting. He suggests that children develop their notion of the world without paying attention to justifiable limitations of logic and experience.

According to Matthews, Piaget's lack of recognition of child's ways of thinking is groundless and he claims that among the conversations described by Piaget one can easily point to those that are a good example of philosophical imagination of children and their potential. In the Piaget Matthews analyses the conversation Piaget had on dreams with Fav, age 8 (MATTHEWS, 1980: 48-51; PIAGET, 1929: 110-113). In this conversation, Piaget is predominantly interested in determining to what extent Fav is still in the Second Stage and to what extent already in the Third Stage. In the Second Stage of child theories about dreams, they assume that dream has its source in head, thought, voice, etc. Children simultaneously assume that dream does happen in the room, before their eyes. In the Third Stage dream is considered a product of thought, happens in head or in the eyes and is an internal phenomenon. In both stages, dream is "produced internally". What sets these stages apart is that in the Second stage the child believes that a dream takes place "in the room in the front of him", whereas in the Third Stage it assumes that it does not happen in the room but "inside the head". On the basis of Fav's answers, Piaget concludes that he is between the Second and Third stage as he seems to want to say two things at once:

(1) During the dream I was in the bed and slept.

(2) During the dream I was next to the bed, in the room.

Eventually, Fav attempts to solve this inconsistency by "multiplying" himself: "There was two of me... I was there twice over". (PIAGET, 1929: 111)

Matthews observes that the expression "during the dream" used in (1) and (2) is ambiguous. If we accept that it means "in the whole of the dream", then (2) true and (1) is false. One can, however, understand this expression differently, as "for the whole period of time in which I had the dream" - then (1) is true and (2) is false. For Matthews, this second solution is not very satisfactory. Someone, who dreamt about himself/herself who was sleeping at the same time is forced to conclude that e.g. at 2 a.m he or she was at the same time in bed and stood next to the bed in the 
room. Piaget himself seems to argue that a proper solution to this conundrum lies in realising that the feeling of externality one might have during a dream is only illusory. Yet Piaget - according to Matthews - convinced about an "internal nature of the dream" - asks Fav: When you sleep, is the dream in you or are you in the dream? and in this way it becomes clear that according to Piaget

(3) The dream is in Fav - is true but

(4) Fav is in the dream - is false.

Matthews is quick to observe that Fav is happy enough to accept (3), but he refuses to give up, and quite rightly so, (4). After all, it was his dream and he knows that he was in it (MATTHEWS, 1980: 53).

According to Matthews, this is one of many examples when Piaget had a chance to engage in philosophical discussion with a child but did not take the advantage of it. His conversation with Fav was aimed at only one thing: to place Fav somewhere along the competence scale. Piaget again turned out to be resistant to puzzlement. Matthews writes:

"How can anybody ask anybody else, adult or child, "Were you in the dream or was the dream in you?" and not succumb to some degree of puzzlement over the naturalness, given a dream with analogous content, of the answer "Both - I was in the dream and dream was in me." Fav is puzzled. Piaget isn't" (MATTHEWS, 1980: 53).

Perhaps the way, in which Piaget understood philosophy itself was of importance as well. As Matthews suggests, his notion of philosophy is closely related to culture, in which he grew up. Continental philosophy (in which Piaget grew up) tended to be more pretentious and more systematic than it was the case in the English-speaking world. The analytic philosophy, which dominates in the Englishspeaking countries, was characterised by a more loose character. This style is closer to child philosophizing than Piaget's, who preferred a more ambitious one. Hence, it comes as no surprise that Piaget described the adulthood as the "phase of formal operations" and assumed that philosophizing requires relevant intellectual predispositions and skills. According to Matthews, Piaget showed that he lacked 
why piaget does not philosophize? critical discussion of gareth $b$. mathews with the piagetan concept of cognitive development

sensitivity to, or appreciation of, or even the patience to, the child's ability to philosophize (MATTHEWS, 1984: 118).

\section{conclusions}

In the view of the above, a question arises whether we really should expect developmental psychology to have something to say about child's ability to philosophize. Let us assume that there is no way of defining a maturity criterion in relation to philosophical thinking and, consequently, that psychology cannot say anything about this ability. Psychologists have more important things to consider that are better suited for their needs and methods of their discipline. On the other hand, however, both teachers and parents often make use of psychological theories and treat them as a guidance in their work with children. It is psychologists that teachers and parents look up to for knowledge on what children like, in what ways do children think and what children are capable of at a given stage. And they do not find any clues on how to treat young philosophers. Matthews puts it this way: "If there is no place in the developmentalist's story for the ability to enter into philosophical dialogue - perhaps because that ability doesn't lend itself to the developmentalist's research strategy - then many teachers and sophisticated parents will not think to engage their children in open philosophical discussion" (MATTHEWS, 1984: 119).

Perhaps then, we should accept that the philosophical curiosity and ability to philosophise emerges in children independently of the cognitive abilities that are the subject matter of psychology? Matthews seems to agree that "cognitive development" is a kind of technical term related to what Piaget described in his experiments. In such a case, philosophy can be considered something peripheral to the cognitive development, independent of all the various ways, in which such process can be understood and explained. Defining age-related stages, when children should ask specific questions is pointless as there is no way of determining the age at which a given problem is relevant for a child and at which it is not. Children seem to 
problematize the world in a spontaneous, natural way and ask truly philosophical questions at different ages.

Since this side of child's mentality is ignored by Piaget as well as the developmental psychologists and education specialists influenced by him, then it is perhaps up to philosophers to point the attention of parents and teachers to this remarkable tendency of children to philosophise. As Matthews argues, children often spontaneously and naturally reconstruct the way of thinking and ideas that can be found in great philosophers. A philosopher, who knows and understands the evolution of European thought, can point to the similarities between the theories developed by children and the philosophical ideas. Being aware of such interrelations can help parents and teachers alike to better understand children and their situation. A philosopher can help them to "(...) recognize philosophy in their children, respect it when it appears, and even participate in it and encourage it on occasion" (MATTHEWS, 1994: 37).

\section{references}

GEACH, P. Mental acts, New York: Bloomsbury Publishing Plc, 1971

MATTHEWS, G.B. Dialogues with Children, Cambridge, Massachusetts and London: Harvard University Press, 1984

MATTHEWS, G.B. Philosophy $\mathcal{E}$ the Young Child, Cambridge, Massachusetts and London: Harvard University Press, 1980

MATTHEWS, G.B. The idea of conceptual development in Piaget. Synthese, vol. 65 (1985), pp. 87-97, 1985

MATTHEWS, G.B. The Philosophy of Childhood, Cambridge, Massachusetts and London: Harvard University Press, 1994

PIAGET, J. The Child's Conception of the World, London: Routledge \& Kegan Paul Ltd, 1929.

PIAGET, J. Children's Philosophies. in: MURCHISON, C. (ed.), A Handbook of Child Psychology, 2nd edition, Worcester, MA: Clark University Press, pp. 534-547, 1933

PIAGET, J., INHELDER, B. The child's Construction of Quantities: Conservation and Atomism, London: Routledge \& Kegan Paul Ltd, 1974

received in: 01.10.2019

accepted in: 14.02 .2019 